\title{
Coronaviruses as the emerging threats for human health: should we be prepared for the future outbreaks of new coronaviruses?
}

\author{
Bahrami R ${ }^{1}$, Hashemi D ${ }^{1}$, Keshavarz Aziziraftar $\mathrm{S}^{2}$, Rahimi $\mathrm{P}^{3}$ \\ Department of Hepatitis and AIDS, Pasteur Institute of Iran, Tehran, Iran. pooneh5376@yahoo.com
}

\begin{abstract}
Recent emergence of SARS-CoV-2 in human communities as the first major zoonotic pandemics of the new millennium following the emergence of SARS-CoV and MERS-CoV has increased our awareness about the future threat of viral zoonosis. Although, several studies have been conducted for better understanding of these viruses` evolution, and designing the effective anti-viral drugs and vaccines, the impact of human beings on occurrence of zoonotic diseases has been less considered and discussed. Improvement in global health resulted in human population growth, increasing demand for animal proteins, more exposures to wildlife, zoonotic and degradation of environment, which have facilitated interspecies transmissions. Since world population is increasing proportionately, the protection of public health against zoonotic diseases is a challenging task. It seems that intensified revision of human lifestyle is the best strategy to prevent the potential devastating future zoonotic pandemics. Herein, the characteristics of SARS-CoV, MERS-CoV, SARS-CoV-2, their transmission routs, their pathogenicity, the therapeutic and prevention approaches including of attempts for designing of effective prophylactic vaccines, anti-viral drugs, and the animal models that have been used for these studies have been reviewed (Ref. 134). Text in PDF www.elis.sk KEY WORDS: SARS-CoV-2, COVID-19, pandemic, zoonosis, SARS, MERS.
\end{abstract}

\section{Introduction}

Coronaviruses belonging to Nidoviral order, and Coronaviridae family, are enveloped viruses with a single stranded positive sense RNA genome with $26-32 \mathrm{~kb}$, which makes them the largest RNA viruses $(1,2)$. Orthocoronavirinae is one of the two sub-family of Coronaviridae which, composed of 4 genera; Alphacoronavirus, Betacoronovirus, Deltacoronavirus, and Gammacoronavirus $(1,2)$ Human coronavirus NL63 (HCoV-NL63), HCoV-229E, porcine respiratory coronavirus (PRCV), porcine transmissible gastroenteritis coronavirus (TGEV), and PEDV are members of alpha-coronaviruses. Beta-coronaviruses are as well divided into 4 lineages; A, B, C, and D. $\beta$-coronaviruses lineage A consists of HCoV-OC43, HCoV-HKU1, while SARS-CoV and SARS-CoV-2 are in the $\beta$-coronaviruses lineage $\mathrm{B}$ ( $\beta$-B coronaviruses), and MERS-CoV is in the $\beta$-coronaviruses lineage $C$. Avian infectious bronchitis coronavirus (IBV) and porcine deltacoronavirus (PdCV)

${ }^{1}$ Department of Microbiology and Microbial Biotech, Shahid Beheshti University, Tehran, Iran, ${ }^{2}$ Department of Mycobacteriology and Pulmonary Research, Pasteur Institute of Iran, Tehran, Iran, and ${ }^{3}$ Department of Hepatitis and AIDS, Pasteur Institute of Iran, 12 Farvardin Ave, Enghelab Square, Tehran, Iran

Address for correspondence: P. Rahimi, Department of Hepatitis and AIDS, Pasteur Institute of Iran, 12 Farvardin Ave, Enghelab Square, Tehran, Iran

Phone: +982166969291 are representative of gamma and deltacoronaviruses respectively (2). Members of this family share structural proteins, the envelop protein $(\mathrm{E})$, the membrane $(\mathrm{M})$, the nucleocapsid protein $(\mathrm{N})$, and spike (S) protein, while some Betacoronaviruses (Betacoronavirus 1) encode a different envelope-associated hemagglutinin-esterase protein (HE) (2-5) . Coronaviruses infect respiratory, gastrointestinal, hepatic, and central nervous system of vertebrates ranging from human, birds, bat, mouse, and many other wild animals (3, 4). Alpha-and betacoronaviruses infect mammals, gammacoronaviruses infect avian species, and deltacoronaviruses infect both mammalian and avian species $(3,4)$. Zoonotic viral diseases such as: Rabies, Ebola, West Nile fever, Crimean-Congo haemorrhagic fever, Dengue fever, Lassa fever, Marburg viral haemorrhagic fever, and Rift Valley fever, which are caused by different viruses` families have been identified for many years $(6,7)$. Four CoVs had been known until 2002: HCoV-229E, HCoV-OC43, HCoVNL63, HKU1 to infect humans causing mostly a mild upper respiratory disease and leading to extreme conditions in infants and old patients in some unusual situations. For the first time, animalto-human and human-to-human transmission was confirmed in an outbreak of severe acute respiratory syndrome (SARS) caused by SARS-Cov in 2002/2003 which was followed by Middle East respiratory syndrome (MERS) caused by MERS-CoV outbreak in 2012 that both viruses infect lower respiratory tract in humans $(4,8$, 9). First report of SARS was an infected human in the Guangdong province of southern China in 2002 (10). It has been found that 


\section{3-741}

horseshoe bats are the natural source of SARS-CoV and civets are their amplification hosts $(11,12)$. In 2003, an epidemic of SARS affected 26 countries and a total of 8,098 people worldwide were infected. After 2003, the outbreak has been vanished. Only small number of cases have been reported due to laboratory accidents or, in some very rare situations through animal-to-human transmission especially in China (10). Close contact of person to person, which increases the risk of virus spreading through droplets produced from patients' coughs, sneeze and stool, was known as the main transmission rout of SARS-CoV. In addition, SARS-CoV could spread through touching eyes, nose or mouth with contaminated fingers, which touched the contaminated surfaces by infectious droplets $(10,13)$. According to the CDC fact sheets, SARS-CoV might be considered as airborne virus, which could spread more broadly through the air (13). Finally, in 2004, implementation of proper infection control practices resulted in a successful ending of that global outbreak $(10,13)$.

In 2012, MERS-CoV outbreak was reported the first case from Saudi Arabia, but further investigations revealed that the first known cases of MERS occurred in Jordan $(14,15)$. Although the exact route(s) of transmission of the MERS-CoV and the role of camels in its transmission remained unknown it has been proposed that dromedary camels are the major source or intermediate host of MERS-CoV $(14,15)$.

In 2019, the World Health Organization (WHO) has recorded 2,428 cases of MERS from 27 countries suffering from this outbreak, resulting in about $43 \%$ mortality $(16,17)$. Most outbreaks (>80 percent) were geographically linked to Saudi Arabia, although travel-related cases occurred in Europe, Asia and Africa (18-20). After detection of SARS-CoV, at least 63 coronaviruses from many animal species were isolated. Recently, a related SARS$\mathrm{CoV}$ and MERS-CoV virus; SARS-CoV-2 (farmer name was 2019-nCoV) emerged and was reported for the first time from patients with mystery pneumonia in Wuhan city in China $(3,4)$. First phylogenetic analysis revealed that, SARS-CoV, MERS-CoV and SRARS-CoV-2 belong to the same genus; betacoronaviruses with the same rout of transmission in human communities albeit, with little differences in their natural origin $(11,12)$. Surprisingly, further analysis of SARS-CoV-2 showed the more distant relation to SARS-CoV and the close sequence relation between bat-SL-CoV ZC45 and bat-SL-CoV ZXC21 with this new coronavirus (4). Like its precedents, this new coronavirus invades low respiratory tract and leads to pneumonia as well, causing multi organ failure like kidney, liver, and central nervous system. So, the related disease was named Coronavirus Disease 2019 (COVID-19), which spreads from person to person through a close contact and droplets via the same routs that were described for SARS and MERS $(20,21)$.

Up to date, there were no confirmed documents about the risk of transfusion transmission of SARS-CoV, MERS-CoV and SARS$\mathrm{CoV}-2$. However, the safety approaches have been recommended such as deferral of blood donation from confirmed COVID-19 recovered patients for at least 28 days after a complete recovery (22-25). The estimation of an average number of people, who could be infected by an active case is called basic reproduction number; $R_{0}$ which could be variable over time because it depends on age, crowdedness, cultural behaviors and location so, there are different estimations of $R_{0}$ for SARS-CoV-2 ranging from 1.4 to 6.49 with the Mean of 3.28 (26). The number of infections/ deaths due to SARS-CoV-2 increased rapidly, therefore restricted containment efforts were urgently needed $(20,27,28)$. Despite of those containments, virus was spread worldwide and finally, in March 2020 World Health Organization declared the COVID-19 as pandemic (29).

This review describes the most famous coronaviruses; SARS$\mathrm{CoV}$, MERS, and SARS-CoV-2 that used to be only in wildlife, but they could overcome the species barriers and caused the severe human health and economic problems threat as well.

\section{Cellular receptors and Cell Entry}

SARS-CoV is an enveloped, single and positive-stranded RNA virus. Its genome RNA encodes 28 proteins, 4 structural proteins, including spike (S), envelope (E), membrane (M) and nucleocapsid $(\mathrm{N})$ proteins, and sixteen non-structural proteins (named nsp1-nsp16) involved in replication such as: RNA dependent RNA polymerase ( $\mathrm{RdRp}$ ), coronavirus main protease (3CLpro), and papain-like protease (PLpro), and the rest are "group-specific" or "accessory proteins" that might have a very important role in the survival of the virus $(30,31)$. The $\mathrm{S}$ protein is a surface glycoprotein precursor with about 1,255 amino acids in length, composed of two subunits; the $\mathrm{S} 1$, which is a receptor-binding domain (RBD) and the $\mathrm{S} 2$ that mediates fusion between the virus and cell membrane (32). The $\mathrm{S}$ protein should be primed to be functional and this priming is done by a host cellular serine protease TMPRSS211, and also, by other proteases like trypsin, and cathepsin $\mathrm{L}$ (32). It has been shown that $\mathrm{S}$ protein is important in induction of neutralizing antibody and cellular immunity $(32,33)$. The main cellular receptor for SARS-CoV is angiotensin-converting enzyme 2 (ACE2) that is recognized and attached by S1 subunit $(33,34)$. However, it can also use alternative receptors, such as DC-SIGN (dendritic cell-specific intercellular adhesion molecule-3-grabbing non-integrin) and/or L-SIGN (liver/lymph node-SIGN) $(35,36)$. After binding of the RBD of S1 to the receptor ACE2, the fusion process is initiated due to the acidic environment of the endosomes (not on the cell surface) through a conformational change of the pre fusion form of S2 to a post-fusion form occurred, leading insertion of the fusion peptide (amino acids 770-788) into the cell membrane $(32,37)$. Two residues at positions 479 and 487 in RBD of S1 protein, determine SARS-CoV tropism and the severity of SARS disease (37). SARS-CoV genome was identified in lung, trachea/bronchus, stomach, small intestine, distal convoluted renal tubule, sweat gland, parathyroid, pituitary, pancreas, adrenal gland, liver and cerebrum; indicating of its ability for infecting multiple organs $(32,37)$. In addition, to understand the routes of virus entry and its pathogenesis, distribution of ACE2 protein was investigated. It was found that ACE2 protein is expressed in many organs such as: lung, liver, kidney, spleen, oral and nasal mucosa, nasopharynx, stomach, small intestine, colon, skin, lymph nodes, thymus, bone marrow, and brain as well as in arterial and venous endothelial cells $(32,38)$. The most remarkable finding was the 
surface expression of ACE2 protein on lung alveolar epithelial cells and enterocytes of the small intestine $(38,39)$. Like other coronaviruses, the MERS-CoV contains a surface spike glycoprotein (S) that interacts with its cellular receptor dipeptidyl peptidase 4 (DPP4 also called CD26) $(40,41)$. Although, the receptor binding domains of the S protein from MERS-CoV and SARS-CoV show a high degree of structural similarity, they are notably divergent in the receptor-binding subdomain, which results in utilization of totally different cellular receptors; as SARS-CoV utilizes ACE2 while MERS-CoV attaches to DPP4 $(40,42)$.

The attachment to DPP4 is followed by proteolytic cleavage of receptor-bound S protein and mediates virus-cell membrane fusion, while this binding also induces the immunosuppression signals, which facilitates viral replication and spread $(42,43)$. More studies showed that the tetraspanin CD9, formed cell-surface complexes of dipeptidyl peptidase 4 (DPP4) and a MERS-CoV-activating type II transmembrane serine protease named (TTSP) to facilitate an early, and efficient entry of virus (43-44).

In 2019, SARS-CoV-2 has been emerged and computer modelling revealed the identical 3-D structures in receptor binging domain of the spike proteins of SARS-CoV-2 and SARS-CoV (46-48). Also, the spike protein of these two viruses share $76.5 \%$ identity in amino acid sequences $(38,48,49)$. However, the studies demonstrated that SARS-CoV-2 S protein could recognize human ACE2 more efficiently and bind to it with a strong affinity (48). This characteristic could explain the higher ability of SARS-CoV-2 for transmission from human to human (49). According to further studies, SARS-CoV-2 does not utilize other coronavirus receptors such as aminopeptidase $\mathrm{N}$ and dipeptidyl peptidase $4(45,46)$.

\section{Symptoms}

Generally, all these viruses have similar incubation period between 2 to 14 days and symptoms such as: influenza-like symptoms that usually begin 2 to 7 days after infection (46). In addition, all three viruses attack the lower respiratory system to cause viral pneumonia, but they also affect kidney, heart, the gastrointestinal system, even central nervous system leading to multiple organ failure $(10,13,32)$. The symptoms range from asymptomatic, paucisymptomatic to severe acute respiratory disease and death and are not specific for a diagnosis of infection with SARS-CoV, MERS-Cov, means SARS-CoV-2 including fever, malaise, myalgia, headache, cough (initially dry), shortness of breath, and diarrhoea are present in the first and/or second week of infection $(10,13)$. Older people or people with medical conditions such as: asthma, diabetes, or heart disease, immunocompromised patients, cancer, renal disease, and chronic lung disease are considered as high risk groups that make severe cases, which often evolve rapidly, progressing to respiratory distress and requiring an intensive care $(10,13,50-51)$. After the virus enters the lung bubbles, macrophages in this area are unable to prevent the spread of infection and in response to the cell's immune response results in the release of cytokines, which causes lung fluid to accumulate and cause severe inflammation. Symptoms such as: abdominal obstruction, hypovolemic shock are very common $(50-51)$. However, there are some little differences in the severity of symptoms between SARS, MERS and COVID-19, for example pneumonia is common in MERS, but not always present (52). Published data about the clinical manifestations of COVID-19 describe the different categories from mild, severe and critical disease. Severe disease cases could be distinguished by dyspnoea, respiratory frequency $\geq 30 / \mathrm{min}$, blood oxygen saturation $\left(\mathrm{SpO}^{2}\right) \leq 93 \%, \mathrm{PaO}_{2} / \mathrm{FiO}_{2}$ ratio, and the percentage of oxygen supplied (fraction of inspired oxygen, $\mathrm{FiO}_{2}$ ) $<300$, and/or lung infiltrates $>50 \%$ within 24 to 48 hours, while in the critical situations other complications such as respiratory failure, septic shock, multiple organ dysfunction (MOD) or failure (MOF) have been reported $(53,54)$. Severe dyspnoea and hypoxemia, renal impairment with a reduced urine output, tachycardia, altered mental status are the main clinical manifestations of sepsis while, acidosis, high lactate, coagulopathy, thrombocytopenia, and hyperbilirubinemia could be considered as the laboratory confirmation of functional alterations of organs $(54,55)$. Also, there are different studies indicating that there might be gender-dependent differences in SARS, MERS, and COVID-19 outcomes $(54,55)$. One study on 2004 showed that males had significantly $(\mathrm{p}<0.0001)$ higher case fatality rate than females did in Hong Kong (55). It has been proposed that estrogen receptor signalling should be considered critical for the protection in females from SARS and MERS, while there are other factors such as copy number of immune response X-linked genes have their own impact on outcomes (56-59). There are some reports of severity of COVID-19 in males compared to females, but more studies are needed $(60,61)$.

\section{Animal models, therapeutic agents and treatment approaches}

Generally, an ideal animal model should support the viral replication and a correlation between virus titer and disease severity. Also, the selected animal should reflect the clinical manifestations such as: the route of infection, and pathology seen in humans (6264). Several inbred strains of mice have been used as SARS-CoV replication models. BALB/c, C57BL6 and 129S were infected via intranasal route and the results showed that $129 \mathrm{~S}$ mice were more susceptible in comparison with BALB/c but, older BALB/c mice showed similar age-dependent susceptibility like human $(65,66)$. Studying on MERS-CoV is more challenging because of the difference between the critical virus spike interaction areas of the human receptor (hDPP4) and mice receptor (DPP4), which makes them resistant to infection by MERS-CoV. This problem has been resolved by a transduction of BALB/c and B6 mice with Ad5-hDPP4 (adenoviral vector expressing hDDP4) so; they could be used for the study on MERS-CoV replication and its clinical manifestations such as: interstitial pneumonia $(67,68)$. Recent pandemic of COVID-19 pushed researchers to develop animal models like mouse models. For example, hACE2 transgenic mouse model is under developing. Rhesus macaques, African green monkeys and cynomolgus macaques have been used in many studies on viral replication, clinical signs and pathology of SARS-CoV and MERS$\mathrm{CoV}$ and they could induce pneumonitis in each species (69-71). However, there were some differences in the outcomes using non- 
human primates as infection with MERS-CoV resulted in a transient pulmonary infection in Rhesus macaques $(63,72)$. Rhesus macaques have been suggested as non-human primates for studying on SARS-CoV-2 infection, but no published data is available yet.

Up to date, there is actually no antiviral treatment with a proven efficacy in humans. There are reports of using interferon alfa-2a in combination with ribavirin and also, remdesivir (GS5734)- an inhibitor of RNA polymerase in multiple RNA viruses-, which showed the effectivity for both prophylaxis and therapy of SARS, MERS. Also recently has been suggested for therapy of COVID-19 the same combination (73-76). Passive immunity suggested to cure these viruses' infections in animal models (77). One study showed that passive immunity by using human monoclonal antibodies could reduce the disease severity of SARS-CoV in golden Syrian hamsters (78). Some investigators suggest that using human monoclonal antibodies could be promising. However, further research is needed also there are some obstacles such as being expensive for massive production (79-89).

Oxygen therapy through mechanical ventilation represents the major treatment for patients with severe respiratory failure caused by SARS-CoV, MERS-CoV and SARS-CoV-2, whereas hemodynamic support is necessary for managing septic shock. It is important that unselective or inappropriate administration of antibiotics should be avoided. However, recent data showed that Azithromycin could reduce the respiratory complications (81-84, 89). There have been many clinical trials testing different agents against MERS-CoV such as: interferon (INF), ribavirin and inhibitors of HIV protease and combination of lopinavir/ritonavir and interferon- $\beta 1 \mathrm{~b}$ (MIRACLE trial) $(85,89,90)$.

In 2013, in Saudi Arabia, the first use of antiviral agents for treating MERS-CoV infection was observed in 5 patients. Unfortunately, all patients died at 1-2 months of respiratory and multiorgan failure and four patients had adverse drug reactions such as: thrombocytopenia, anaemia and pancreatitis. All the patients obtained oral and subcutaneous interferon alfa-2b ribavirin (85, 89). In 2015, two patients with MERS-Cov infection in Kuwait underwent subcutaneous and oral ribavirin therapy with pegylated interferon alfa-2b. Within 42 days after starting antiviral therapy, one patient was sent home, and ribavirin was stopped due to anaemia within one week of treatment. The second patient survived from MERS-CoV, and died with multidrug-resistant organism two months later $(85,90)$.

Another small study used ribavirin and interferon-alfa $2 \mathrm{~b}$ in three patients receiving care within 1-2 days of admission and was matched with three other patients receiving treatment 12-19 days after admission. The first group survived and the second group passed away $(85,87)$. Lopinavir / ritonavir has been used in conjunction with ribavirin and IFN- $\alpha 2 \mathrm{a}$ and resulted in virus clearance, and survival in treatment of MERS patients in Korea while the similar treatment in Greece was not effective; viral RNA remained detectable and the patients died $(90,91)$. Although, the HIV protease inhibitors, Nelfinavir and lopinavir, were criteria for inhibiting SARS-CoV and MERS-CoV based on SARS results, there are some controversies on using this combination for the treatment of COVID-19 as Cao et al. reported that WHO researchers did not find any clinical improvement or mortality rate or even reduction of viral RNA in patients 'specimens by treatment with lopinavir-ritonavir $(91,92)$.

Chloroquine, and its derivatives including hydroxychloroquine and chloroquine phosphate are the most effective drugs for the treatment of severe acute respiratory syndrome. However, cardiotoxicity with prolonged use has been reported in patients with immunosuppression, hepatic or renal dysfunction (93-97). Up to date there is no FDA-approved and specific antiviral drug for the treatment of patients infected with SARS-COV-2 so, the clinical management such as infection prevention and control measures and supportive care, including supplementary oxygen and mechanical ventilation are the best curative things that could be done. Several investigational drugs are under evaluation and different treatment protocols are being revised based on the clinical trial results. Remdesivir, developed by Gilead Sciences Inc., is one of the investigational antiviral drugs that causes premature termination of RNA transcription and its combination with Chloroquine showed the promising inhibitory effects in-vitro on SARS-CoV-2 replication (98). Also, it shows the same effect on other beta-coronaviruses such as SARS-CoV and Mers-CoV in-vitro and in-vivo (99). Favipiravir (known as T-705), is a purine nucleoside, which leads to an inaccurate viral RNA synthesis in many RNA viruses and was originally developed by Toyama Chemical of Japan (99-103). This anti-virus RNA dependent RNA polymerase is currently being studied in phase III clinical trials in both China and the USA (105). There are reports that using Favipiravir could be the most available and effective treatment for COVID-19 $(100,106)$.

Very recently, human recombinant soluble ACE2 (hrsACE2) was designed and evaluated on Vero cells, engineered human blood vessel, and human kidney organoids (107). The results showed that this recombinant soluble ACE2 could inhibit the replication of SARS-CoV-2 at early stage by a factor of 1000-5000 in Vero cells and also, in engineered human blood vessel and kidney organoids (107). However, it did not show the same effect on mouse rsACE2. The similar compound; GSK2586881, and APN01 was used in a randomized, double-blind, placebo-controlled investigation for the treatment of SARS, but it did not show significant changes in the clinical outcome $(108,109)$.

\section{Vaccine candidates}

Efforts towards developing a vaccine for SARS, and MERS have led to patent different types of viral vaccines like: inactive or live-attenuated viruses, virus-like particle (VLP), viral vectors, protein-based, DNA-based, and mRNA-based vaccines. Up to date, 15 patents disclose information about inactive and live-attenuated virus vaccines, 13 patents disclose information on VLP vaccines, DNA vaccines have been disclosed in 28 patent, 21 patents described information on viral vector vaccines, and three patents are focused on mRNA vaccines $(110,111)$. The results of vaccine trials showed that viral $\mathrm{S}$ protein subunit vaccines produced higher neutralizing antibody titers and were more effective than DNAbased $S$ protein vaccines, full-length $S$ protein, and live-attenuated SARS-CoV (111-115). 
Inactivated SARS-CoV-based vaccines, S protein-based vaccines, and vaccines based on fragments containing neutralizing epitopes are the most in progress vaccine candidates for SARSCoV (111-115).

Vaccine candidates for MERS include DNA vaccine albeit with a low effectiveness human MERS vaccines for long-term protection of people at high exposure risk and for reactive use in outbreak (116-119). Although multiple attempts are in progress to develop a vaccine against COVID-19, up to date no vaccine has completed clinical trials. There are some reports of Clinical trials of vaccine candidates such as an RNA vaccine (mRNA-1273) from the USA and other countries $(120,121)$.

\section{Discussion}

Viruses consist of only genetic materials (DNA or RNA) which, means that with some differences, they have a very high capacity for different kinds of genomic mutations (transition, transversion, insertion, deletion, recombination, reassortment, etc), and adaptation to variety of hosts and conditions. Also, they could transfer genes between different hosts from different species that makes them the most effective creatures in evolution. Breaking the "species barriers" and compromise with a new host due to the genomic mutations is the main key of their survival. Zoonotic viral diseases like Rabies, Spanish flu, swine flu, Yellow fever, Hantavirus, HIV, and Ebola have spread from animals to humans $(1,3,125,126)$. Development of human civilization resulted in human population growth, increase in life expectancy and need for more expansion of villages, cities, farms, concomitant with special nutrition cultures that caused more contact between human and animals; therefore, increasing interactions facilitated a perpetuated transmission of animal viruses to human $(6-9,125-$ 127). The Spanish flu pandemic with $500,000,000$ infected people and at least 50,000,000 deaths worldwide was the first pandemic of a viral disease (128). The causative virus was an H1N1 virus with genes of avian origin (130). The second pandemic of a new strain of H1N1 virus (pdm09 virus) named swine flu was in 2009 (128). It caused about 700,000,000 to 1.4 billion infections with 150,000 to 575,000 fatalities (132). Despite of SARS, MERS, and COVID-19 we have lots of knowledge about influenza virus, its effective vaccine has been up- dated annually, and specific drugs for treatment are available. The most serious health problems caused by coronaviruses occurred at the early phase of SARS epidemic in the 2002 and 2003, the prototype group consisting of three viral genome sequences of animal origin was identified as the evolutionary starting point as they showed a low-pathogenicity due to six amino acid substitutions of the $\mathrm{S}$ protein, and in the second epidemic (2003-2004), more amino acid alterations (about 11) again in $\mathrm{S}$ protein resulting in a high-pathogenicity virus group $(55,96,106,112,133)$. Since then scientists have been interested in following the coronaviruses and several studies were conducted to understand their evolutionary trend. Bioinformatics' analysis revealed that spike protein (S) acts as the cellular receptor binding, fusion protein, and is the most immunogenic viral protein, which induces the production of neutralizing antibodies, So, this protein is under the host immune system pressure and has to be evolved rapidly. Recently, a sequence analysis revealed $89.8 \%$ sequence identity between SARS-CoV and SARS-CoV-2 S2 subunit of their spike (S) proteins, while both of their $\mathrm{S} 1$ subunits utilize the same cellular receptor (ACE2) (133). However, it has been shown that the higher infectivity and transmissibility of SARS-CoV-2 compared to SARS-CoV is because of the higher ACE2-binding affinity (about 10- to 20-fold) of the receptor binding domain (RBD) in S1 subunit of SARS-COV-2 $(127,128)$. These findings resulted in introducing SARS-CoV-2 as an emerging virus, which caused severe health problems in the world $(96,133)$.

Emerging of SARS and MERS with mortality rates of about 10 and $43 \%$ respectively, with no cure or vaccine to combat with, impressed the human health strategy makers with contact precautions such as: travel restrictions, and patient isolation were recommended to limit transmission of those viruses $(63,64,96,133)$. Since in late of 2019 , we are dealing with the similar situation again, keeping social/physical distance, "staying at home" or in some more restricted conditions "quarantine" accompanied with a frequent hand washing, disinfection of hands and surfaces by using disinfectants such as alcohol, and wearing the mask are strongly recommended to reduce COVID-19 $(63,64,133)$. Although we are used to encounter with epidemics or even pandemics due to re-emerging of some mutant viruses like HIV or influenza virus with new characteristics in their virulence, tropisms, and genomic information, recent outbreaks of emerging viruses from other viral families such as: SARS, MERS, Ebola, and COVID-19 in a time rang of about 20 years might be the warning of potential viral diseases outbreaks in the next future. Zoonoses with the ability of interspecies transmission are responsible for most emerging infectious diseases. Therefore, the ideal approach for preventing from future outbreaks could be the intensified monitoring of zoonosis and antiviral strategies involving small molecules and biologics targeting complex molecular interactions in viral infections also recent pandemic of SARS-CoV-2 highlights the necessity for the rapid development of effective interventions against these highly pathogenic coronaviruses.

\section{References}

1. Family - Coronaviridae; Virus taxonomy. Ninth Report of the International Committee on Taxonomy of Viruses 2012, 806-828. https://doi. org/10.1016/B978-0-12-384684-6.00068-9.

2. Li F. Structure, Function, and Evolution of Coronavirus Spike Proteins. Annu Rev Virol 2016; 29; 3 (1): 237-261. DOI:10.1146/annurevvirology-110615-042301.

3. Wang LF, Shi Z, Zhang S, Field H, Daszak P, Eaton B. Review of bats and SARS. Emerg Infect Dis 2006; 12 (12): 1834-1840. DOI: 10.3201/eid1212.060401.

4. Chen Y, Guo D. Molecular mechanisms of coronavirus RNA capping and methylation. Virol Sin 2016; 31 (1): 3-11. DOI: 10.1007/s12250016-3726-4.

5. Fehr AR, Perlman S. Coronaviruses: An Overview of Their Replication and Pathogenesis. Methods Mol Biol 2015; 1282: 1-23. DOI: 10.1007/9781-4939-2438-7_1. 
6. Galvani AP. Emerging Infections: What Have We Learned from SARS? Emerg Infec Dis 2004; 10 (2): 1351-1352. DOI: 10.3201/eid1007.040166.

7. Kilpatrick AM, Daszak P, Jones MJ, Marra PP, Kramer LD. Host heterogeneity dominates West Nile virus transmission. Proc Biol Sci 2006; 273 (1599): 2327-2333. DOI: 10.1098/rspb.2006.3575.

8. Kuiken T, Fouchier RA, Schutten $M$ et al. Newly discovered coronavirus as the primary cause of severe acute respiratory syndrome. Lancet 2003; 362: 263-270. DOI: 10.1016/S0140-6736(03)13967-0.

9. Galvani AP, Lei X, Jewell NP. Severe acute respiratory syndrome: temporal stability and geographic variation in case-fatality rates and doubling times. Emerg Infect Dis 2003; 9: 991-994. DOI: 10.3201/eid0908.030334.

10. https://www.who.ith.diseases/sars/en.SARS (Severe Acute Respiratory Syndrome).

11. Cheng VCC, Lau SKP, Woo PCY, Yuen KY. Severe Acute Respiratory Syndrome Coronavirus as an Agent of Emerging and Reemerging Infection. Clin Microbiol Rev 2007; 20 (4): 660-694. DOI: 10.1128/ CMR.00023-07.

12. Breugelmans JG, Zucs Ph, Porten K, Broll S, Niedrig M, Ammon A, Krause G. SARS transmission and commercial aircraft. Emerg Infect Dis 2004; 10 (8): 1502-1503. DOI: 10.3201/eid1008.040093.

13. www.cdc.gov/sars/about/fs-sars.

14. https://www.cdc.gov/coronavirus/mers/downloads/factsheet-mers_ en.pdf.Centers for Disease Control and Prevention. Middle East Respiratory Syndrome (MERS).

15. http://apps.who.int/mediacentre/factsheets/mers-cov/en/index. html.

16. Matthews KL, Coleman CM, van der Meer Y, Snijder EJ, Frieman MB. The ORF4b-encoded accessory proteins of Middle East respiratory syndrome coronavirus and two related bat coronaviruses localize to the nucleus and inhibit innate immune signaling. J Gen Virol 2014; 95 (Pt 4): 874-882. DOI: 10.1099/vir.0.062059-0.

17. Momattin H, Al-Ali AY, Al-Tawfiq JA. A Systematic Review of therapeutic agents for the treatment of the Middle East Respiratory Syndrome Coronavirus (MERS-CoV). Travel Med Infect Dis 2019; 30: 9-18. DOI: 10.1016/j.tmaid.2019.06.012.

18. Arabi YM, Balkhy HH, Hayden FG et al. Middle East respiratory syndrome. N Engl J Med 2017; 376 (6): 584-594. DOI: 10.1056/NEJMsr1408795.

19. Mizumoto K, Chowell G. Estimating Risk for Death from 2019 Novel Coronavirus Disease, China, January-February2020. Emerg Infect Dis 2020; 26 (6). DOI: 10.3201/eid2606.200233.

20. Kucharski AJ, Russell TW, Diamond Ch et al. Early dynamics of transmission and control of COVID-19: a mathematical modelling study. Lancet Infect Dis 2020; 20: 30144-30144. https://doi.org/10.1016/S14733099(20)30144-4 .

21. Wang Y, Wang Y, Chen Y, Qin Q. Unique epidemiological and clinical features of the emerging 2019 novel coronavirus pneumonia (COVID-19) implicate special control measures. J Med Virol 2020; 1-9. DOI: 10.1002/jmv.25748.

22. Shang G, Biggerstaff BJ, Yang B, Shao C, Farrugia A. Theoretically estimated risk of severe acute respiratory syndrome transmission through blood transfusion during an epidemic in Shenzhen, Guangdong, China in 2003. Transfus Apher Sci 2007; 37: 233-240. http://doi.org/10.1016/j. transci.2007.09.004.
23. Poon TC, Chan KC, Ng PC et al. Serial analysis of plasma proteomic signatures in pediatric patients with severe acute respiratory syndrome and correlation with viral load. Clin Chem 2004; 50: 1452-1455. http://doi. org/10.1373/clinchem.2004.035352.

24. Schmidt M, Brixner V, Ruster B, Hourfar MK, Drosten C. NAT screening of blood donors for severe acute respiratory syndrome coronavirus can potentially prevent transfusion associated transmissions. Transfusion 2004; 44: 470-475. http://doi.org/10.1111/j.1537-2995. 2004.03269.x.

25. American Association of Blood Banks. Update: impact of 2019 novel coronavirus and blood safety, http://www.aabb.org/advocacy/regulatorygovernment/Documents/Impact-of-2019-Novel-Coronavirus-on-BloodDonation.pdf; 2020 [accessed 2020-2-5].

26. Liu Y, Gayle AA, Wilder-Smith A, Rocklöv J. The reproductive number of COVID-19 is higher compared to SARS coronavirus. J Travel Med 2020; 27 (2): 1-4. https://doi.org/10.1093/jtm/taaa021.

27. Li Q, Guan X, Wu P et al. Early transmission dynamics in Wuhan, China, of novel coronavirus-infected pneumonia. N Engl J Med 2020; 382 (13): 1199-1207. DOI:10.1056/NEJMoa2001316.

28. Liu T, Hu J, Kang M et al. Transmission dynamics of 2019 novel coronavirus (2019-nCoV). bioRxiv 2020; published online Feb 13. DOI:10.1101/2020.01.25.919787.

29. https://www.who.int/docs/default-source/coronaviruse/20200312sitrep-52-covid-19.pdf. Coronavirus disease 2019 (COVID-19) Situation Report -52 .

30. Du L, He Y, Zhou Y, Liu Sh, Zheng BJ, Jiang Sh. The spike protein of SARS-CoV - a target for vaccine and therapeutic development. Nat Rev Microbiol 2009; 7 (3): 226-236. DOI: 10.1038/nrmicro2090.

31. Narayanan K, Huang Ch, Makino Sh. SARS coronavirus accessory proteins. Virus Res 2008; 133(1): 113-121. DOI: 10.1016/j.virusres.2007.10.009.

32. Xu Y, Lou Zh, Liu Y et al. Crystal structure of severe acute respiratory syndrome coronavirus spike protein fusion core. J Biol Chem 2004; 279 (47): 49414-49419. DOI: 10.1074/jbc.M408782200.

33. Kuba, K, Imai Y, Rao S et al. A crucial role of angiotensin converting enzyme 2 (ACE2) in SARS coronavirus-induced lung injury. Nat Med 2005; 11(8): 875-879. DOI: 10.1038/nm1267.

34. Li W, Moore M J, Vasilieva N et al. Angiotensin-converting enzyme 2 is a functional receptor for the SARS coronavirus. Nature 2003; 426 (6965): 450-454. DOI: 10.1038/nature02145.

35. Jeffers S A, Tusell SM, Gillim-Ross L et al. CD209L (L-SIGN) is a receptor for severe acute respiratory syndrome coronavirus. Proc Natl Acad Sci 2004; 101 (44): 15748-15753. https://doi.org/10.1073/ pnas.0403812101.

36. Yang Z Y, Huang Y, Ganesh $L$ et al. pH-dependent entry of severe acute respiratory syndrome coronavirus is mediated by the spike glycoprotein and enhanced by dendritic cell transfer through DC-SIGN. J Virol 2004; 78 (11): 5642-5650. DOI: 10.1128/JVI.78.11.5642-5650. 2004.

37. AC, YJ, Tortorici MA, Wall A, McGuire AT, Veesler D. Structure, Function, and Antigenicity of the SARS-CoV-2 Spike Glycoprotein. Cell 2020; 180: 1-12. https://doi.org/10.1016/j.cell.2020.02.058].

38. Gu J, Gong E, Zhang B et al. Multiple organ infection and the pathogenesis of SARS. J Exp Med 2005; 202 (3): 415-424 18. DOI: 10.1084/ jem. 20050828 . 
39. Ding Y, He L, Zhang Q et al. Organ distribution of severe acute respiratory syndrome (SARS) associated coronavirus (SARS-CoV) in SARS patients: implications for pathogenesis and virus transmission pathways. J Pathol 2004; 203: 622-630. DOI: 10.1002/path.1560.

40. Hamming I, Timens W, Bulthuis MLC, Lely AT, Navis GJ, van Goor H. Tissue distribution of ACE2 protein, the functional receptor for SARS coronavirus: a first step in understanding SARS pathogenesis. J Pathol 2004; 203: 631-663. DOI: 10.1002/path.1570.

41. Wang N, Shi X, Jiang L et al. Structure of MERS-CoV spike receptorbinding domain complexed with human receptor DPP4. Cell Res 2013; 23: 986-993. https://doi.org/10.1038/cr.2013.92.

42. Raj VS, Smits SL, Provacia LB et al. Adenosine deaminase acts as a natural antagonist for dipeptidyl peptidase 4-mediated entry of the Middle East respiratory syndrome coronavirus. J Virol 2014; 88: 1834-1838. DOI: 10.1128/JVI.02935-13.

43. Gao J, Lu G, Qi J et al. Structure of the fusion core and inhibition of fusion by a heptad repeat peptide derived from the $\mathrm{S}$ protein of Middle East respiratory syndrome coronavirus. J Virol 2013; 87 (24): 13134-13140. DOI: $10.1128 /$ JVI.02433-13.

44. Mubarak A, Alturaiki W, Hemida MG. Middle East Respiratory Syndrome Coronavirus (MERS-CoV): Infection, Immunological Response, and Vaccine Development. J Immunol Res 2019; 2019: 1-11. https://doi. org/10.1155/2019/6491738.

45. Earnest JT, Hantak MP, Li K, McCray PB Jr, Perlman S, Gallagher T. The tetraspanin CD9 facilitates MERS-coronavirus entry by scaffolding host cell receptors and proteases. PLoS Path 2017; 13(7): e1006546. DOI: 10.1371/journal.ppat.1006546.

46. Lu G, Wang Q, Gao G F. Bat-to-human: spike features determining 'host jump' of coronaviruses SARS-CoV, MERS-CoV, and beyond. Trends Microbiol 2015; 23 (8): 468-478. DOI: 10.1016/j.tim.2015.06.003.

47. Wan Y, Shang J, Graham R, Baric RS, Li F. Receptor recognition by novel coronavirus from Wuhan: an analysis based on decade-long structural studies of SARS. J Virol 2020; 94 (7): 1-9. https://doi.org/10.1128/ jvi.00127-20.

48. Xu X, Chen P, Wang J et al. Evolution of the novel coronavirus from the ongoing Wuhan outbreak and modeling of its Spike protein for risk of human transmission. Sci China Life Sci 2020; 63: 457-460. https://doi. org/10.1007/s11427-020-1637.

49. Li F, Li W, Farzan M, Harrison SC. Structure of SARS Coronavirus Spike Receptor Binding Domain Complexed with Receptor. Science 2005; 309 (5742): 1864-1868. DOI: 10.1126/science. 1116480.

50. Letko M, Marzi A, Munster V. Functional assessment of cell entry and receptor usage for SARS-CoV-2 and other lineage B betacoronaviruses. Nat Microbiol 2020; 5: 562-569. https://doi.org/10.1038/s41564-020-0688-y.

51. Lauer SA, Grantz KH, Bi Q et al. The incubation period of coronavirus disease 2019 (COVID-19) from publicly reported confirmed cases: Estimation and application. Ann Intern Med 2020; M20-0504: 1-7. https:// doi.org/10.7326/M20-0504.

52. Sherbini N, Iskandrani A, Kharaba A, Khalid G, Abduljawad M, Al-Jahdali H. Middle East respiratory syndrome coronavirus in Al-Madinah City, Saudi Arabia: demographic, clinical and survival data. J Epidemiol Glob Health 2017; 7 (1): 29-36. DOI: 10.1016/j.jegh.2016.05.002.

53. Subbaram K, Kannan H, Gatasheh MK. Emerging Developments on Pathogenicity, Molecular Virulence, Epidemiology and Clinical Symptoms of Current Middle East Respiratory Syndrome Coronavirus (MERSCoV). HAYATI 2017; 24 (2): 53-56. DOI: 10.1016/j.hjb.2017.08.001.
54. Drosten C, Seilmaier M, Corman VM et al. Clinical features and virological analysis of a case of Middle East respiratory syndrome coronavirus infection. Lancet Infect Dis 2013; 13 (9): 745-751. DOI: 10.1016/ S1473-3099(13)70154-3.

55. https://www.who.int/news-room/fact-sheets/detail/middle-east-respiratory-syndrome-coronavirus-(mers-cov) 2019.

56. Singer M, Deutschman CS, Seymour CW et al. The Third International Consensus Definitions for Sepsis and Septic Shock (Sepsis-3). JAMA 2016; 315 (8): 801-810. DOI: 10.1001/jama.2016.0287.

57. Karlberg J, Chong DSY, Lai WYY. Do Men Have a Higher Case Fatality Rate of Severe Acute Respiratory Syndrome than Women Do? Am J Epidemiol 2004; 159 (3): 229-231, https://doi.org/10.1093/aje/kwh056.

58. Channappanavar R, Fett C, Mack M, Eyck PPT, Meyerholz DK, Perlman S. Sex-based differences in susceptibility to SARS-CoV infection. J Immunol 2017; 198 (10): 4046-4053. DOI: 10.4049/jimmunol.1601896.

59. Klein SL, Flanagan KL. Sex differences in immune responses. Nature Rev Immunol 2016; 16: 626-638. DOI: 10.1038/nri.2016.90.

60. Klein SL. Implications of X-linked gene regulation for sex differences in disease pathogenesis (comment on DOI 10.1002/bies.201100047) BioEssays 2011; 33: 789-790.

61. Klein SL. The effects of hormones on sex differences in infection: from genes to behavior. Neurosci Biobehav Rev 2000; 24: 627-638. DOI: 10.1016/s0149-7634(00)00027-0.

62. https://www.cdc.gov/coronavirus/2019-ncov/publications.html.

63. Report of the WHO-China Joint Mission on Coronavirus Disease 2019 (COVID-19) [Pdf] - World Health Organization, Feb. 28, 2020.

64. Gordon CJ, Tchesnokov EP, Feng JY, Porter DP, Gotte M. The antiviral compound remdesivir potently inhibits RNA-dependent RNA polymerase from Middle East respiratory syndrome coronavirus. J Biol Chem 2020; pii: jbc.AC120.013056. DOI: 10.1074/jbc.AC120.013056. [Epub ahead of print].

65. de Wit E, Feldmann F, Cronin J et al. Prophylactic and therapeutic remdesivir (GS-5734) treatment in the rhesus macaque model of MERSCoV infection. Proc Natl Acad Sci USA 2020; 117 (12): 6771-6776. DOI: 10.1073/pnas.1922083117.

66. Gretebeck LM, Subbarao K, Animal models for SARS and MERS coronaviruses. Curr Opin Virol 2015; 13: 123-129. DOI: 10.1016/j.coviro.2015.06.009.

67. Glass WG, Subbarao K, Murphy B, Murphy PM. Mechanisms of host defense following severe acute respiratory syndrome-coronavirus (SARS-CoV) pulmonary infection of mice. J Immunol 2004; 173 (6): 4030-4039. DOI: https://doi.org/10.4049/jimmunol.173.6.4030.

68. Subbarao K, McAuliffe J, Vogel L et al. Prior infection and passive transfer of neutralizing antibody prevent replication of severe acute respiratory syndrome coronavirus in the respiratory tract of mice. J Virol 2004; 78 (7): 3572-3577. DOI: 10.1128/jvi.78.7.3572-3577.2004.

69. Cockrell AS, Peck KM, Yount BL et al. Mouse dipeptidyl peptidase 4 is not a functional receptor for Middle East respiratory syndrome coronavirus infection. J Virol 2014; 88 (9): 5195-5199. DOI: 10.1128/ JVI.03764-13.

70. Zhao J, Li K, Wohlford-Lenane $\mathrm{C}$ et al. Rapid generation of a mouse model for Middle East respiratory syndrome. Proc Natl Acad Sci USA 2014; 111: 4970-4975. DOI: 10.1073/pnas.1323279111. 
733-741

71. McAuliffe J, Vogel L, Roberts A et al. Replication of SARS coronavirus administered into the respiratory tract of African Green, rhesus and cynomolgus monkeys. Virology 2004; 330: 8-15. DOI: 10.1016/j. virol.2004.09.030.

72. Rowe T, Gao G, Hogan RJ et al. Macaque model for severe acute respiratory syndrome. J Virol 2004; 78: 11401-11404. DOI: 10.1128/ JVI.78.20.11401-11404.

73. Fouchier RA, Kuiken T, Schutten M et al. Koch's postulates fulfilled for SARS virus. Nature 2003; 423: 240. DOI: 10.1038/423240a.

74. Yao Y, Bao L, Deng W et al. An animal model of MERS produced by infection of rhesus macaques with MERS coronavirus. J Infect Dis 2014; 209: 236-242. DOI: 10.1093/infdis/jit590].

75. Martinez MA. Compounds with therapeutic potential against novel respiratory 2019 coronavirus. Antimicrob Agents Chemother. 2020 Mar 9. pii: AAC.00399-20. DOI: 10.1128/AAC.00399-20.

76. Zhu JD, Meng W, Wang XJ, Wang HChR. Broad-spectrum antiviral agents. Front Microbiol 2015; 6: 517. DOI: 10.3389/fmicb.2015.00517.

77. Elshabrawy HA, Fan J, Haddad CS et al. Identification of a BroadSpectrum Antiviral Small Molecule against Severe Acute Respiratory Syndrome Coronavirus and Ebola, Hendra, and Nipah Viruses by Using a Novel High-Throughput Screening Assay. J Virol 2014; 88 (8): 4353-4365. DOI: 10.1128/JVI.03050-13.

78. Channappanavar R, Lu L, Xia S et al. Protective effect of intranasal regimens containing peptidic Middle East respiratory syndrome coronavirus fusion inhibitor against MERS-CoV infection. J Infect Dis 2015; 212 (12): 1894-1903. DOI: 10.1093/infdis/jiv325.

79. Ishii K, Hasegawa $\mathbf{H}$, Nagata $\mathbf{N}$ et al. Neutralizing antibody against severe acute respiratory syndrome (SARS)-coronavirus spike is highly effective for the protection of mice in the murine SARS model. Microbiol Immunol 2009; 53 (2): 75-82. DOI: 10.1111/j.1348-0421.2008.00097.

80. Roberts A, Thomas WD, Guarner $\mathbf{J}$ et al. Therapy with a severe acute respiratory syndrome-associated coronavirus-neutralizing human monoclonal antibody reduces disease severity and viral burden in golden Syrian Hamsters. J Infect Dis 2006; 193 (5): 685-692. https://doi. org/10.1086/500143.

81. Prabakaran P, Zhu Z, Xiao X et al. Potent human monoclonal antibodies against SARS CoV, Nipah and Hendra viruses. Expert Opin Biol Ther 2009; 9(3):355-68. DOI: 10.1517/14712590902763755.

82. Coughlin MM, Prabhakar BS. Neutralizing human monoclonal antibodies to severe acute respiratory syndrome coronavirus: target, mechanism of action, and therapeutic potential. Rev Med Virol 2012; 22 (1): 2-17. DOI: $10.1002 / \mathrm{rmv} .706$.

83. Elshabrawy HA, Coughlin MM, Baker SC, Prabhakar BS. Human monoclonal antibodies against highly conserved HR1 and HR2 domains of the SARS-CoV spike protein are more broadly neutralizing. PLoS One 2012; 7 (11): e50366. DOI: 10.1371/journal.pone.0050366.

84. ter Meulen J, van den Brink EN, Poon LL et al. Human monoclonal antibody combination against SARS coronavirus: synergy and coverage of escape mutants. PLoS Med 2006; 3 (7): e237. DOI: 10.1371/journal. pmed.0030237.

85. Greenough TC, Babcock GJ, Roberts A et al. Development and characterization of a severe acute respiratory syndrome-associated coronavirus-neutralizing human monoclonal antibody that provides effective immunoprophylaxis in mice. J Infect Dis 2005; 191 (4): 507-514. DOI: $10.1086 / 427242$.
86. Tian X, Li C, Huang A et al. Potent binding of 2019 novel coronavirus spike protein by a SARS coronavirus-specific human monoclonal antibody. Emerg Microbes Infect 2020; 9 (1): 382-385. DOI: 10.1080/22221751.2020.1729069.

87. Arabi YM, Alothman A, Balkhy HH et al. Treatment of Middle East respiratory syndrome with a combination of lopinavir-ritonavir and interferon- $\beta 1 \mathrm{~b}$ (MIRACLE trial): study protocol for a randomized controlled trial. Trials. 2018; 19 (1): 81. DOI: 10.1186/s13063-017-2427-0.

88. Al-Tawfiq JA, Momattin H, Dib J, Memish ZA. Ribavirin and interferon therapy in patients infected with the Middle East respiratory syndrome coronavirus: an observational study. IJID 2014; 20: 42-46. DOI: 10.1016/j.ijid.2013.12.003.

89. Chan JF, Chan K-H, Kao RY et al. Broad-spectrum antivirals for the emerging Middle East respiratory syndrome coronavirus. J Infect 2013; 67 (6): 606-616. DOI: 10.1016/j.jinf.2013.09.029.

90. Kim UJ, Won EJ, Kee SJ, Jung SI, Jang HC. Combination therapy with lopinavir/ritonavir, ribavirin and interferon- $\alpha$ for Middle East respiratory syndrome. Antiviral Ther 2016; 21 (5): 455-459. DOI: 10.3851/ IMP3002.

91. Spanakis N, Tsiodras S, Haagmans BL et al. Virological and serological analysis of a recent Middle East respiratory syndrome coronavirus infection case on a triple combination antiviral regimen. Int $\mathrm{J}$ Antimicrob Agents 2014; 44 (6): 528-532. DOI: 10.1016/j.ijantimicag. 2014.07.026.

92. Chu CM, Cheng VC, Hung IF et al. Role of lopinavir/ritonavir in the treatment of SARS: initial virological and clinical findings. Thorax 2004; 59: 252-256. DOI: 10.1136/thorax.2003.012658.

93. Chan KS, Lai ST, Chu CM et al. Treatment of severe acute respiratory syndrome with lopinavir/ritonavir: a multicenter retrospective matched cohort study. Hong Kong Med J 2003; 9: 399-406. PMID: 14660806.

94. Cao B, Wang Y, Wen D et al. A Trial of Lopinavir-Ritonavir in Adults Hospitalized with Severe Covid-19. NEJM 2020; DOI: 10.1056/NEJMoa2001282.

95. https://www.cdc.gov/coronavirus/2019-ncov/hcp/therapeutic-options.html\#r1.

96. Colson P, Rolain JM, Lagier JC, Brouqui P, Raoult D. Chloroquine and hydroxychloroquine as available weapons to fight COVID-19. Int J Antimicrob Agents 2020; 55 (4): 105932. DOI: 10.1016/j.ijantimicag.2020.105932. [Epub ahead of print].

97. Yao X, Ye F, Zhang M et al. In Vitro Antiviral Activity and Projection of Optimized Dosing Design of Hydroxychloroquine for the Treatment of Severe Acute Respiratory Syndrome Coronavirus 2 (SARS-CoV-2). Clin Infect Dis 2020; pii: ciaa237. DOI: 10.1093/cid/ciaa237. [Epub ahead of print].

98. Gao J, Tian Z, Yang X. Breakthrough: Chloroquine phosphate has shown apparent efficacy in treatment of COVID-19 associated pneumonia in clinical studies. Biosci Trends 2020; 14 (1): 72-73. DOI: 10.5582/ bst.2020.01047.

99. Gautret P, Lagier J, Parola P et al. Hydroxychloroquine and azithromycin as a treatment of COVID-19: results of an open-label non-randomized clinical trial. INT J ANTIMICROB AG. In Press. https://doi. org/10.1016/j.ijantimicag.2020.105949.

100. Wang M, Cao R, Zhang $L$ et al. Remdesivir and chloroquine effectively inhibit the recently emerged novel coronavirus (2019-nCoV) in vitro. Cell Res 2020; 30 (3): 269-271. DOI: 10.1038/s41422-020-0282-0. 
101. Sheahan TP, Sims AC, Graham RL et al. Broad-spectrum antiviral GS-5734 inhibits both epidemic and zoonotic coronaviruses. Sci Trans1 Med. 2017; 9 (396). DOI: 10.1126/scitranslmed.aal 3653.

102. Maxmen, A. More than 80 clinical trials launch to test coronavirus treatments. Nature 2020; 578 (7795):347-348. DOI: 10.1038/d41586-02000444-3.

103. Furuta Y, Takahashi K, Shiraki K et al. T-705 (favipiravir) and related compounds: Novel broad-spectrum inhibitors of RNA viral infections. Antiviral Res 2009; 82 (3): 95-102. DOI: 10.1016/j.antiviral.2009.02.198.

104. Furuta Y, Gowen BB, Takahashi K, Shiraki K, Smee DF, Barnard DL. Favipiravir (T-705), a novel viral RNA polymerase inhibitor. Antiviral Res. 100 (2): 446-454. DOI: 10.1016/j.antiviral.2013.09.015.

105. Caroline AL, Powell DS, Bethel LM, Oury TD, Reed DS, Hartman AL. Broad spectrum antiviral activity of favipiravir (T-705): protection from highly lethal inhalational Rift Valley Fever". PLOS Neglected Tropical Diseases. 8 (4): e2790. DOI: 10.1371/journal.pntd.0002790.

106. Jin Z, Smith LK, Rajwanshi VK, Kim B, Deval J. The ambiguous base-pairing and high substrate efficiency of T-705 (Favipiravir) Ribofuranosyl 5'-triphosphate towards influenza A virus polymerase". PLOS One 2013; 8 (7): e68347. Bibcode:2013PLoSO...868347J. DOI: 10.1371/ journal.pone.0068347.

107. Cai Q, Yang M, Liu D et al. Experimental Treatment with Favipiravir for COVID-19: An Open-Label Control Study. Engineering 2020. In Press. https://doi.org/10.1016/j.eng.2020.03.007.

108. Huaxia. Favipiravir shows good clinical efficacy in treating COVID-19: official. Xinhuanet.com, 17 March 2020.

109. Dong L, Hu S, Gao J. Discovering drugs to treat coronavirus disease 2019 (COVID-19). Drug Discov Ther 2020; 14 (1): 58-60. DOI: 10.5582/ddt.2020.01012.

110. Monteil V, Kwon H, Prado $P$ et al. Inhibition of SARS-CoV-2 infections in engineered human tissues using clinical-grade soluble human ACE2. Cell Press 2020. DOI: 10.1016/j.cell.2020.04.004.https://www.cell. $\mathrm{com} / \mathrm{pb}$ assets/products/coronavirus/CELL_CELL-D-20-00739.

111. Haschke M, Schuster M, Poglitsch $M$ et al. Pharmacokinetics and pharmacodynamics of recombinant human angiotensin-converting enzyme 2 in healthy human subjects. Clin Pharmacokinet 2013; 52 (9): 783-792. DOI: 10.1007/s40262-013-0072-7.

112. Khan A, Benthin C, Zeno B et al. A pilot clinical trial of human recombinant angiotensin-converting enzyme 2 in acute respiratory distress syndrome. Crit Care 2017; 21 (1): 234. DOI: 10.1186/s13054-017-1823-x.

113. Liu C, Zhou Q, Li Y et al. Research and Development on Therapeutic Agents and Vaccines for COVID-19 and Related Human Coronavirus Diseases. ACS Cent Sci 2020; 6: 315 -331. https://dx.DOI.org/10.1021/ acscentsci.0c00272.

114. Jiang Sh, He Y, Liu Sh. SARS Vaccine Development. Emerging Infectious Diseases 2005; 11(7):1016-1020. • www.cdc.gov/eid •

115. He Y, Zhou Y, Siddiqui P, Jiang S. Inactivated SARS-CoV vaccine elicits high titers of spike protein-specific antibodies that block receptor binding and virus entry. Biochem Biophys Res Commun 2004; 325 : 445-452. DOI: 10.1016/j.bbrc.2004.10.052.

116. Bisht H, Roberts A, Vogel L et al. Severe acute respiratory syndrome coronavirus spike protein expressed by attenuated vaccinia virus protectively immunizes mice. Proc Natl Acad Sci USA 2004; 101: 6641-6646. DOI: 10.1073/pnas.0401939101.

117. He Y, Zhou Y, Wu H et al. Identification of immunodominant sites on the spike protein of severe acute respiratory syndrome (SARS) coronavirus: implication for developing SARS diagnostics and vaccines. J Immunol 2004; 173: 4050-4057. DOI: https://doi.org/10.4049/jimmunol.173.6.40.

118. Du L, Zhao G, He Y et al. Receptor-binding domain of SARS-CoV spike protein induces long-term protective immunity in an animal model. Vaccine 2007; 25 (15): 2832-2838. DOI: 10.1016/j.vaccine.2006.10.031.

119. See RH, Zakhartchouk AN, Petric $M$ et al. Comparative evaluation of two severe acute respiratory syndrome (SARS) vaccine candidates in mice challenged with SARS coronavirus. J Gen Virol 2006; 87 (Pt 3): 641-650. DOI: 10.1099/vir.0.81579-0.

120. Zumla A, Memish ZA, Hui DS, Perlma S. Vaccine against Middle East respiratory syndrome coronavirus. Lancet Infect Dis 2019; 19 : 1054-1055. DOI: https://doi.org/10.1016/S1473-3099(19)30477-3.

121. Modjarrad K, Roberts CC, Mills KT et al. Safety and immunogenicity of an anti-Middle East respiratory syndrome coronavirus DNA vaccine: a phase 1, open-label, single-arm, dose-escalation trial. Lancet Infect Dis 2019; 19: 1013-1022. DOI: 10.1016/S1473-3099(19)30266-X.

122. Yoon I-K, Kim JH. First clinical trial of a MERS coronavirus DNA vaccine. Lancet Infect Dis 2019; 19: 924-925. DOI: 10.1016/S14733099(19)30397-4.

123. Schindewolf C, Menachery VD. Middle East respiratory syndrome vaccine candidates: cautious optimism. Viruses 2019; 11: e74. DOI: 10.3390/v11010074.

124. Amanat F, Krammer F. SARS-CoV-2 Vaccines: Status Report. Immunity 2020. In Press. https://doi.org/10.1016/j.immuni.2020.03.007.

125. Chen WH, Strych U, Hotez PJ, Bottazzi ME. The SARS-CoV-2 Vaccine Pipeline: an Overview. Curr Trop Med Rep 2020: 1-4. DOI: 10.1007/s40475-020-00201-6. [Epub ahead of print].

126. Simani S, Fayaz A, Rahimi P, Eslami N, Howeizi N, Biglari P. Six fatal cases of classical rabies virus without biting incidents, Iran 1990-2010. JCV 2012; 54 (3): 251-254. https://doi.org/10.1016/j.jcv.2012.03.009.

127. Rahimi P, Sohrabi A, Ashrafihelan J, Edalat R, Mehran Alamdari, Masoudi MH, Mostofi S, and Azadmanesh K. Emergence of African Swine Fever Virus, Northwestern Iran. Emerg Infect Dis 2010; 16 (12): 1946-1948. DOI: 10.3201/eid1612.100378.

128. Rahimi P, Vahabpour R, Aghasadeghi MR, Sadat SM, Howaizi N, Mostafavi E, Eslamifar A, Fallahian V. Correction: Neutralizing Antibody Response after Intramuscular Purified Vero Cell Rabies Vaccination (PVRV) in Iranian Patients with Specific Medical Conditions. PLoS ONE 2015; 10 (10): e0142244. https://doi.org/10.1371/journal.pone.0142244.

129. https://www.cdc.gov/flu/pandemic-resources/1918-pandemic-h1n1. html.

130. https://www.cdc.gov/flu/pandemic-resources/2009-h1n1-pandemic. html.

131. First Global Estimates of 2009 H1N1 Pandemic Mortality Released by CDC-Led Collaboration. cdc.gov. 25 June 2012. Retrieved 31 January 2020.

132. Xia S,Liu M, Wang C etal. Inhibition of SARS-CoV-2 (previously 2019$\mathrm{nCoV}$ ) infection by a highly potent pan-coronavirus fusion inhibitor targeting its spike protein that harbors a high capacity to mediate membrane fusion. Cell Res 2020; 30: 343-355. https://doi.org/10.1038/s41422-020-0305-x.

133. Zhou P, Yang XL, Wang XG et al. A pneumonia outbreak associated with a new coronavirus of probable bat origin. Nature 2020; 579 (7798): 270-273. DOI: 10.1038/s41586-020-2012-7.

134. Emerging Infectious Diseases www.cdc.gov/eid Vol. 10, No. 7, July 2004.

Received April 30, 2020. Accepted May 2, 2020. 